\title{
Tear production and intraocular pressure values in clinically normal eyes of whooper swans (Cygnus cygnus)
}

\author{
Liga Kovalcuka ${ }^{1, *}$, Dmitrij Boiko² and David L. Williams ${ }^{3}$ \\ ${ }^{1}$ Latvia University of Life Sciences and Technologies, Faculty of Veterinary Medicine, Clinical Institute, K. \\ Helmana iela 8, Jelgava, LV-3004, Latvia \\ ${ }^{2}$ Institute of Biology, University of Latvia, Miera 3, Salaspils, LV-2169, Latvia \\ ${ }^{3}$ Department of Veterinary Medicine, University of Cambridge, Cambridge CB3 OES, UK
}

\begin{abstract}
The objective of this study was to determine the normal range of tear production and values of intraocular pressure (IOP) in clinically normal eyes of whooper swans (Cygnus cygnus). A total of 86 birds: 81 cygnets (6-10 weeks old) and 5 moulting - adult swans (3-6 years old) were examined in this study. Both eyes of all birds underwent a complete ophthalmic examination, including evaluation of tear production with the phenol red thread test (PRTT) and the assessment of the IOP by rebound tonometry, employing the TonoVet ${ }^{\circledR}$ device. The mean \pm standard deviation of PRTT values were as follows: all cygnets (81) $22.59 \pm 3.48 \mathrm{~mm} / 15 \mathrm{~s}$, male cygnets (45) $22.64 \pm 3.54 \mathrm{~mm} / 15 \mathrm{~s}$, female cygnets (36) $22.53 \pm 3.44 \mathrm{~mm} / 15 \mathrm{~s}$. IOP was as follows: all cygnets $11.30 \pm 3.55 \mathrm{mmHg}$, male cygnets $10.93 \pm 3.56$ $\mathrm{mmHg}$, female cygnets $11.74 \pm 3.50 \mathrm{mmHg}$. No statistically significant differences between right and left eye and between female and male cygnets were found for IOP and PRTT values. This study provides the reference values for the PRTT and IOP in healthy whooper swan cygnets, showing that PRTT determination of the tear production and rebound tonometry to evaluate the IOP methods are practical methods for ophthalmic examination in swans.
\end{abstract}

Keywords: Eye, Intraocular pressure, Phenol red thread test, Tear production, Whooper swan.

\section{Introduction}

There are seven swan species in the world (Brazil, 2003) and three of them are common in Latvia. One of these, the whooper swan (Cygnus cygnus L.) was found to breed only in North Russia and Scandinavia. Nowadays the breeding population of whooper swans has expanded its habitat southwards and its breeding population has become more stable by increasing in number in southern Scandinavia and the Baltic States (Haapanen, 1989; Axbrink, 1999). The species has been breeding in Germany, Denmark, Ukraine, Belarus, Hungary and the Netherlands (Abramchuk et al., 2003; Grell et al., 2004; Gaschak, 2005; Bauer and Woog 2008; Van Dijk et al., 2010).

The first nesting whooper swan in Latvia was found in 1973 (Baumanis, 1975), but by 2007 the population had reached about 200 pairs (Boiko, 2008).

The whooper swan is listed in the International Union for Conservation of Nature (IUCN) Red Data Book (IUCN, 2017) and the EU Birds Directive, Appendix II). There are difficulties in performing a proper examination in birds with ocular diseases brought into veterinary clinics for treatment and rehabilitation with the aim of re-releasing healthy treated birds into the wild because of the limited diagnostic methods and knowledge of physiological ocular parameters of the healthy swan eye. Therefore, it is important to establish normal ophthalmic parameters for the exotic animals such as wild birds. In the literature, normal values of ocular diagnostic tests have been published for domestic and wild animals (Ofri et al., 2002; MontianiFerreira et al., 2008; Lange et al., 2012), and lately in water birds, ducks, and geese (Mood et al., 2016).

Data are limited for many species, and there are currently no data available for swans. Standard ophthalmic diagnostic tests such as assessment of the intraocular pressure (IOP) with rebound tonometry and tear production with the phenol red thread test (PRTT) are very important to provide a complete ophthalmic examination in birds (Stiles et al., 1994; Holt et al., 2006; Jeong et al., 2007; Storey et al., 2009; Barsotti et al., 2013).

The purpose of this study was to determine the physiologic values of tear production in clinically normal whooper swans, using the PRTT and IOP measurement using the rebound $\mathrm{TonoVet}^{\circledR}$ tonometer.

\section{Material and Methods}

The field study was performed near the most important ringing sites for cygnets and adult non-breeding birds, namely the fish ponds in Skrunda ( $\left.56^{\circ} 42^{\prime} \mathrm{N}, 21^{\circ} 59^{\prime} \mathrm{E}\right)$, Renda $\left(57^{\circ} 04^{\prime} \mathrm{N}, 22^{\circ} 17^{\prime} \mathrm{E}\right)$ and Rimzāti $\left(56^{\circ} 58^{\prime} \mathrm{N}\right.$, $\left.22^{\circ} 10^{\prime} \mathrm{E}\right)$ in Latvia.

The study was performed fully respecting the welfare of the birds involved and the ethical criteria under 
which the bird identification ringing was performed. The research has been approved by the ethics committee of the Latvia University of Life Sciences and Technologies. Birds were restrained in a specifically designed Velcro jacket thus immobilizing the birds' body, feet, legs, and wings, with no pressure exerted on cervical region (Fig. 1). The neck was held in by the hand because whooper swans do not show any aggression and specific precautions are not needed. Bird capture, fixation, and ringing were performed according to internationally accepted guidelines (FAO, 2007).

A physical examination was performed before the ocular examination, and any animals with indications of systemic diseases were excluded from our study. An examination was performed by DVM, Dr.med.vet., an associate professor, specializing in veterinary ophthalmology. All birds included in this study were examined to ensure they were ophthalmologically healthy. Ocular examination included direct ophthalmoscopy (Keeler Practitioner, Windsor, UK), monocular direct ophthalmoscopy (PanOptic $^{\circledR}$ ophthalmoscope, Welch Alynn, Romford, UK), slit lamp biomicroscopy (Kowa SL15, Nagoya, Aichi, Japan), and fundus photography (SmartscopeVet $2^{\circledR}$ fundus camera, Sonomed Oy Ltd, Finland). A total of 86 birds, 81 healthy wild cygnets (45 males and 36 females) and 5 healthy adult birds ( 2 males and 3 females) were examined in this study. Sex and age was identified by the researcher group according to physiological and anatomical features (Demongin, 2016). The exact age of the birds was unknown, but cygnets (Fig. 2) ranged between 6-10 weeks of age and adult birds (Fig. 3) were between 3-6 years. The birds were classified into groups, differentiated by age and gender: all cygnets, male cygnets and female cygnets respectively and adult birds. To measure tear production, the PRTT was employed, using a single lot from one manufacturer (Tianjin Jingming New Technological Development Co., Ltd.). To perform the PRTT the non-toothed Wangensteen tissue forceps were used to facilitate placement of the 3-mm indentation at the end of the thread into the inferior conjunctival sac for the 15 seconds. After the removal of the test, the length of the strip for which the color changed from yellow to red was immediately measured in millimetres. All tonometric measurements were performed by the same person employing rebound tonometry with the Tonovet tonometer (TonoVet ${ }^{\circledR}$, Tiolat Ltd. Finland) in the (d) calibration setting, with automatic calibration as provided by the device. Each measurement recorded was the automatically generated average after five successive readings. Measurements were taken between incursions of the nictitating membrane and care was taken not to apply pressure to the neck or periocular region.

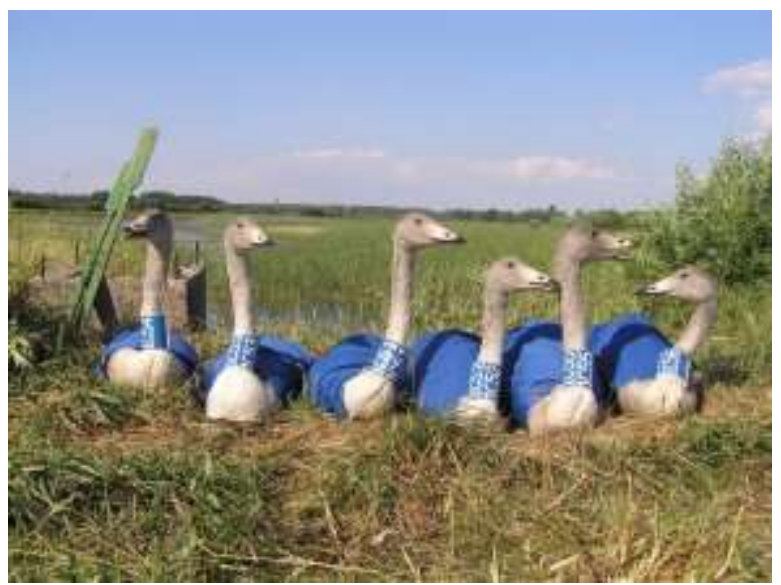

Fig. 1. Whooper swans restrained in a specifically designed Velcro jacket.

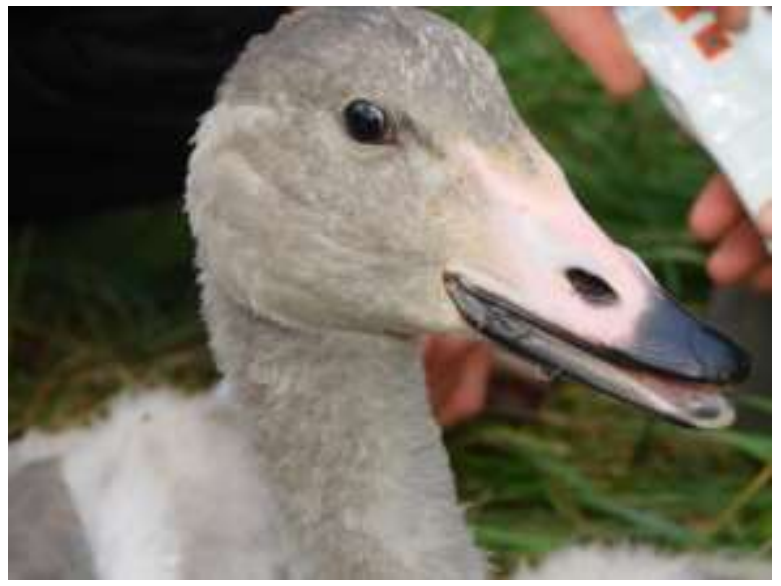

Fig. 2. Whooper swan cygnet.

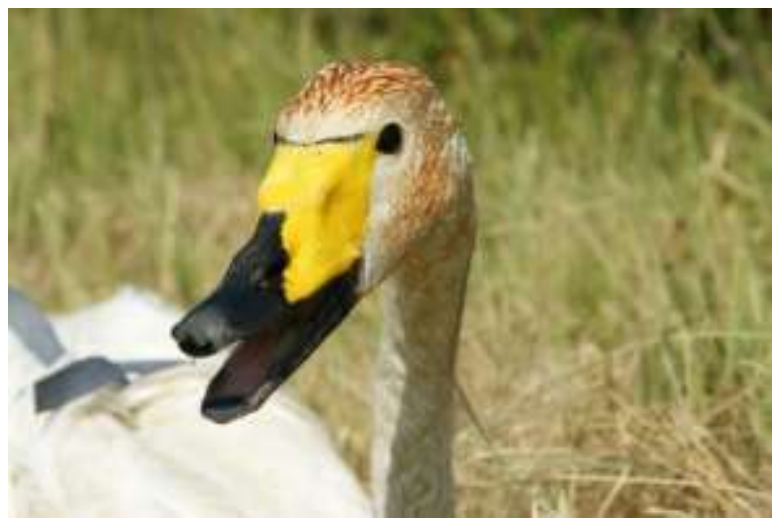

Fig. 3. Whooper swan adult (Moulting birds).

\section{Statistical methods}

Statistical analysis of the data was performed using statistical software programs SPSS and Microsoft Excel. Arithmetic mean values (X) and standard deviation (SD) of the PRTT and IOP results were obtained from each eye separately. Normality was tested using the one-sample Kolmogorov-Smirnow test. 
A paired sample t-test was used to compare the PRTT obtained from the right and left eye. An independent sample t-test was used to compare the mean PRTT and IOP values for bird's age and sex. P values less than 0.05 were considered to be statistically significant.

\section{Results}

The PRTT threads were placed without difficulty facilitated by the use of the forceps. The birds tolerated all the tests well. All numeric data obtained for PRTT test and IOP values in the population used in this study were normally distributed according to the Kolmogorov-Smirnow test. Measurements of PRTT in all 86 birds showed a mean \pm SD of $22.5 \pm 3.63 \mathrm{~mm} / 15 \mathrm{~s}$ in both eyes, as presented in Table 1, with a median of $23 \mathrm{~mm} / 15 \mathrm{~s}$ in the right and left eyes, showing no significant differences between eyes $(\mathrm{P}>0.05)$. For cygnets, the mean PRTT value was $22.59 \pm 3.48 \mathrm{~mm} / 15 \mathrm{~s}$ in both eyes of, with no difference in cygnets between the right and left eye measurement (Table 1). The mean PRTT in male cygnets for both eyes was $22.64 \pm 3.54$ $\mathrm{mm} / 15 \mathrm{~s}$, whereas the mean PRTT in females was $22.53 \pm 3.44 \mathrm{~mm} / 15 \mathrm{~s}$ respectively. Comparison between mean PRTT values in male and female birds showed no significant difference $(\mathrm{P}>0.05)$. For the adult bird group (5 birds) the average of PRTT values was $21 \pm 5.57 \mathrm{~mm} / 15 \mathrm{~s}$ in both eyes. The PRTT results in all bird groups showed no significant difference between PRTT values in birds of different age and gender and between right and left eye $(\mathrm{P}>0.05)$.

IOP in all 86 birds showed a mean \pm SD of $11.19 \pm 3.48$ $\mathrm{mmHg}$ in both eyes with a median of $10 \mathrm{mmHg}$ in the right and left eyes (Table 2), and no significant differences between left and right eyes $(\mathrm{P}>0.05)$. IOP mean values in cygnets was $11.30 \pm 3.55 \mathrm{mmHg}$ both eyes. Mean IOP in male cygnets in both eyes was $10.93 \pm 3.56 \mathrm{mmHg}$, whereas in female cygnets were $11.74 \pm 3.50 \mathrm{mmHg}$. In the adult bird group (Table 2), the average of IOP values was $9.5 \pm 1.27 \mathrm{mmHg}$ in both eyes, showing no significant differences in IOP values between both eyes $(\mathrm{P}>0.05)$, but values were significantly lower than in cygnets $(\mathrm{P}<0.05)$. The IOP results in all bird groups showed no significant difference between birds of different age and sex $(\mathrm{P}>0.05)$.

\section{Discussion}

This study provides reference ranges for PRTT and IOP in normal eyes of whooper swans, mainly relating to cygnets. Establishing normal ranges in healthy birds is very important to avoid diagnostic misinterpretations during ophthalmic examination and this is a relevant in swans as in other avian species.

To the authors' knowledge, PRTT and IOP values have not previously been reported in swans. Both tests are relatively easy to perform, however, active third eyelid movements can make it difficult to keep the PRTT thread in the lower conjunctival sac.
Table 1. Phenol Red Thread test values for the whooper swans.

\begin{tabular}{lcccc}
\hline \multirow{2}{*}{ Groups } & \multirow{2}{*}{$\begin{array}{c}\text { No. of } \\
\text { birds }\end{array}$} & \multicolumn{3}{c}{ Mean PRTT \pm SD (mm/15s) } \\
\cline { 3 - 5 } & & Right eye & Left eye & Both eyes \\
\hline $\begin{array}{l}\text { All } \\
\text { birds }\end{array}$ & 86 & $22.35 \pm 3.56$ & $22.35 \pm 3.72$ & $22.5 \pm 3.63$ \\
$\begin{array}{l}\text { Adult } \\
\text { birds }\end{array}$ & 5 & $20.6 \pm 5.22$ & $21.4 \pm 6.5$ & $21.0 \pm 5.58$ \\
$\begin{array}{l}\text { All } \\
\text { cygnets }\end{array}$ & 81 & $22.46 \pm 3.44$ & $22.72 \pm 3.54$ & $22.59 \pm 3.48$ \\
$\begin{array}{l}\text { Male } \\
\text { cygnets }\end{array}$ & 45 & $22.58 \pm 3.48$ & $22.71 \pm 3.63$ & $22.64 \pm 3.54$ \\
$\begin{array}{l}\text { Female } \\
\text { cygnets }\end{array}$ & 36 & $22.30 \pm 3.43$ & $22.75 \pm 3.47$ & $22.53 \pm 3.44$ \\
\hline
\end{tabular}

Table 2. Intraocular pressure values for the whooper swans.

\begin{tabular}{lcccc}
\hline \multirow{2}{*}{ Groups } & \multirow{2}{*}{$\begin{array}{c}\text { No. of } \\
\text { birds }\end{array}$} & \multicolumn{3}{c}{ Mean $\mathrm{IOP} \pm \mathrm{SD}(\mathrm{mmHg})$} \\
\cline { 3 - 5 } & & Right eye & Left eye & Both eyes \\
\hline $\begin{array}{l}\text { All } \\
\text { birds }\end{array}$ & 86 & $11.26 \pm 3.35$ & $11.13 \pm 3.63$ & $11.19 \pm 3.48$ \\
$\begin{array}{l}\text { Adult } \\
\text { birds }\end{array}$ & 5 & $9.4 \pm 0.54$ & $9.6 \pm 1.81$ & $9.5 \pm 1.27$ \\
$\begin{array}{l}\text { All } \\
\text { cygnets }\end{array}$ & 81 & $11.38 \pm 3.41$ & $11.22 \pm 3.70$ & $11.30 \pm 3.55$ \\
$\begin{array}{l}\text { Male } \\
\text { cygnets }\end{array}$ & 45 & $11.02 \pm 3.44$ & $10.84 \pm 3.71$ & $10.93 \pm 3.56$ \\
$\begin{array}{l}\text { Female } \\
\text { cygnets }\end{array}$ & 36 & $11.81 \pm 3.37$ & $11.67 \pm 3.68$ & $11.74 \pm 3.50$ \\
\hline
\end{tabular}

We found the PRTT to be as an appropriate test to use for tear production measurement in these birds because of the small size of the eye, eyelid fissure and it has shown restrictions when used in small eyes (Willis and Wilkie, 1999; Müller et al., 2010). Also with the shorter test time period taken for this test that the Schirmer tear test (STT) and the lower level of tear production compared to the dog or cat in which the STT is widely used (Holt et al., 2006; Storey et al., 2009; Barsotti et al., 2013).

All measurements were performed at approximately the same time of the day $(9.00 \mathrm{am}-12.00 \mathrm{pm})$ because of the possible diurnal variation in tear production and IOP (Beech et al., 2003; Hartley et al., 2006) and by the same examiner with the bird held in the same body position to minimize variations in restraint or study technique.

Data for wild animal species mostly concerns mammalian groups but we considered it inappropriate to compare our data with mammals, therefore we identified similar studies investigating other avian species. So far evaluation of normal tear production in large Psittaciformes like the cockatoo, macaw, Amazon, African grey, Eclectus and Pionus species showed mean PRTT test values $19.8 \pm 4.3 \mathrm{~mm} / 15 \mathrm{~s}$ in the right eye and $20.1 \pm 3.9 \mathrm{~mm} / 15 \mathrm{~s}$ in the left eye, somewhat lower than the values for the swans in the current study (Holt et al., 2006; Storey et al., 2009; Barsotti et al., 2013) but they do have smaller eyes than 
those of the swans investigated here. These large Psittaciforme birds were studied in northeast United States were the mean temperature in summer is an average of $80^{\circ} \mathrm{F}\left(26.8^{\circ} \mathrm{C}\right)$ and relative humidity is $71 \%$ (Holt et al., 2006), compared to Latvia where mean temperature in summer is $64^{\circ} \mathrm{F}\left(17.8^{\circ} \mathrm{C}\right)$ and relative humidity is $76 \%$ (Latvian Environment, Geology and Meteorology Centre). These differences may relate to differences in environment quite as much as ocular anatomy or physiology. Previously Barsotti and colleagues have shown tear production also in Eurasian Tawny owls, Little owls, Common buzzards, and European kestrels (Barsotti et al., 2013), however, we used the PRTT test instead of STT.

A previous study has shown that after positioning of threads in the fornix of upper and lower eyelids, the PRTT values of the common Mynah birds were $17.5 \pm 3.1 \mathrm{~mm} / 15 \mathrm{~s}$ and $19.2 \pm 2.5 \mathrm{~mm} / 15 \mathrm{~s}$, respectively, showing a significant difference between PRTT values for upper eyelids and lower eyelids (Rajaei et al., 2015). In our study, we placed PRTT in the lower eyelid and results show $22.59 \pm 3.48 \mathrm{~mm} / 15 \mathrm{~s}$ in the cygnet group and $22.5 \pm 3.63 \mathrm{~mm} / 15 \mathrm{~s}$ in all-bird group showing somewhat higher results than the current study. These differences might be explained by the differences in lifestyle - the Common Mynah (Acridotheres tristis) is an omnivorous living open woodland bird but the whooper swan is a water bird.

In research in geese and ducks, which are similar to swans in both their ocular anatomy and the environment in which they live, the Schirmer tear test was used to evaluate tear production showing values of $6.2 \pm 2.2 \mathrm{~mm} / \mathrm{min}$ in ducks and $5.5 \pm 2.6 \mathrm{~mm} / \mathrm{min}$ in geese, but these data are difficult to compare to those in the present study because of the different methods of evaluating tear production (Mood et al., 2016).

Regarding measurement of avian IOP, a study in Screech owls determined the mean IOP to be $9 \pm 1.8$ $\mathrm{mmHg}$ measured with TonoVet "d" calibration but $11 \pm 1.9 \mathrm{mmHg}$ measured with TonoPen-KL, showing lower IOP with TonoVet (Harris et al., 2008) while measurement of IOP with the TonoPen mean values varied between $9.83 \pm 3.41 \mathrm{mmHg}$ in little owls and $8.53 \pm 1.59 \mathrm{mmHg}$ in European kestrels to $17.2 \pm 3.53$ $\mathrm{mmHg}$ in Common buzzards (Reuter et al., 2011). The IOP values in our study lie between these two values at $11.19 \pm 3.48 \mathrm{mmHg}$ measured with TonoVet tonometer. Another study suggested that the rebound tonometer possibly overestimates IOP values in diurnal raptors and underestimate IOP values in nocturnal raptors but the variations from the manometric value in these birds was small and varied between species (Reuter et al., 2010, 2011). Considering the differences in the present study between young and adult birds, a study in three week old chickens, showed IOP values of $17.51 \pm 0.13$ $\mathrm{mmHg}$, that did not differ significantly with broiler and layer chickens lines (Prashar et al., 2007), but again it should be noted that these are not water birds. In one study of captive black-footed penguins (Spheniscus dermersus) tonometry showed a much higher IOP $(31.77 \pm 3.3 \mathrm{mmHg}$ ) than in our study (GonzalesAlonso-Alegre et al., 2015), and a later publication of ocular findings and reference values in penguins showed IOP measured with the Tonovet tonometer " $\mathrm{d}$ " calibration to be $29.1 \pm 7.16 \mathrm{mmHg}$ in Macaroni and $24.1 \pm 5.09 \mathrm{mmHg}$ in Rockhopper penguin, both higher than in swans evaluated here (Bliss et al., 2015). A more recent research study on IOP in ducks and geese showed the average IOP to be $10.2 \pm 2.2 \mathrm{mmHg}$ in ducks and $9.1 \pm 2.0 \mathrm{mmHg}$ in geese, measured with TonoVet tonometer (calibrated at the " $\mathrm{d}$ " setting as in the current study) giving results similar to those in the present study (Mood et al., 2016).

To conclude, the investigation of clinical parameters obtained in this study will help veterinary ophthalmologists and wild animal veterinarians to evaluate changes in tear production and IOP in swans more accurately to help further in the treatment of wild birds. Further study of the diurnal variation of the physiological parameters like tear production and IOP should be undertaken and is planned by the current authors.

\section{Conflict of interest}

The authors declare that there is no conflict of interest.

\section{References}

Abramchuk, A.V., Abramchuk, S.V. and Prokopchuk, V.V. 2003. Whooper Swan (Cygnus cygnus): a new breeding species for Belarus. Subbuteo. 6, 6-9.

Axbrink, M. 1999. Sångsvanen ökar, resultat från riksinventeringen. Vår Fågelvärld. 58(3), 10-16.

Barsotti, G., Briganti, A., Spratte, J.R., Ceccherelli, R. and Breghi, G. 2013. Schirmer tear test type I readings and intraocular pressure values assessed by applanation tonometry (Tonopen $₫$ XL) in normal eyes of four European species of birds of prey. Vet. Ophthalmol. 16(5), 365-369.

Bauer, H.G. and Woog, F. 2008. Non-native and naturalised bird species (neozoa) in Germany, part I: occurrence, population size and status. Vogelwarte. 46, 157-194.

Baumanis, J. 1975. Nesting of Whooper Swan (Cygnus cygnus L.) in Latvia. Zoologijas Muzeja Raksti. 12, 79-81.

Beech, J., Zappala, R.A., Smith, G. and Lindborg, S. 2003. Schirmer tear test results in normal horses and ponies: effect of age, season, environment, sex, time of day and placement of strips. Vet. Ophthalmol. 6(3), 251-254.

Bliss, C.D., Aquino, S. and Woodhouse, S. 2015. Ocular findings and reference values for selected ophthalmic diagnostic tests in the macaroni penguin 
(Eudyptes chrysolophus) and southern rockhopper penguin (Eudyptes chrysocome). Vet. Ophthalmol. 18(1), 86-93.

Boiko, D. 2008. Territorial and temporal distribution of Whooper Swan Cygnus cygnus marked with neck collars in Latvia in $2003-2005$. Acta Universitatis Latviensis. Biol. 745, 53-61.

Brazil, M. 2003. The Whooper Swan. T. \& A.D. Poyser. London.

Demongin, L. 2016. Identification guide to birds in the hand. Beauregard-Vernon, pp: 243-244.

FAO. 2007. Wild Birds and Avian Influenza: an introduction to applied field research and disease sampling techniques. Edited by: Whitworth, D., Newman, S.H., Mundkur, T. and Harris, P. FAO Animal Production and Health Manual, No. 5. Rome. (also available at: www.fao.org/avianflu).

Gaschak, S.P. 2005. About breeding of Whooper Swan in the Chornobyl zone of Ukraine. Berkut. 14(2), 269-270.

Gonzales-Alonso-Alegre, E.M., Martinez-Nevado, E. and Caro-Vadillo, A. 2015. Central corneal thickness and intraocular pressure in captive blackfooted penguins (Spheniscus dermersus). Vet. Ophthalmol. 18(1), 94-96.

Grell, M.B., Heldbjerg, H., Rasmussen, B., Stabell, M., Tofft, J. and Vikstrøm, T. 2004. Rare and threatened breeding birds in Denmark, 1998-2003. Dansk Ornitologisk Forenings Tidsskrift. 98, 45-100.

Haapanen, A. 1989. Whooper Swan Cygnus c. cygnus population dynamics in Finland. In Proceedings of the Third IWRB International Swan Symposium. Sears, J. and Bacon, P.J., eds., Oxford. Wildfowl, Suppl. 1, pp: 137-141.

Harris, M.C., Schorling, J.J., Herring, I.P., Elvinger, F., Bright, P.R. and Pickett, J.P. 2008. Ophthalmic examination findings in a colony of Screech owls (Megascops asio). Vet. Ophthalmol. 11, 186-192.

Hartley, C., Williams, D.L. and Adams, V.J. 2006. Effect of age, gender, weight, and time of day on tear production in normal dogs. Vet. Ophthalmol. 9(1), 53-57.

Holt, E., Rosenthal, K. and Shofer, F.S. 2006. The phenol red thread tear test in large Psittaciformes. Vet. Ophthalmol. 9(2), 109-113.

IUCN. 2017. The IUCN Red List of Threatened Species. Version 2017-3.

Jeong, M.B., Kim, Y.J., Yi, N.Y., Park, S.A., Kim, W.T., Kim, S.E., Chae, J.M., Kim, J.T., Lee, H. and Seo, K.M. 2007. Comparison of the rebound tonometer (TonoVet) with the applanation tonometer (TonoPen XL) in normal Eurasian Eagle owls (Bubo bubo). Vet. Ophthalmol. 10, 376-379.

Lange, R., Lima, L. and Montiani-Ferreira, F. 2012. Measurement of tear production in black-tufted marmosets (Callithrix penicillata) using three different methods: modified Schirmer's I, phenol red thread and standardized endodontic absorbent paper points. Vet. Ophthalmol. 15, 1-7.

Montiani-Ferreira, F., Truppel, J., Tramontin, M.H., Vilani, R.G. and Lange, R.R. 2008. The capybara eye: clinical tests, anatomic and biometric features. Vet. Ophthalmol. 11(6), 386-394.

Mood, M., Rajaei, S.M., Ghazanfari Hashemi, S., Williams, D.L. and Sadjadi, R. 2016. Measurement of tear production and intraocular pressure in ducks and geese. Vet. Ophthalmol. 20(1), 53-57.

Müller, K., Mauler, D.A. and Eule, J.C. 2010. Reference values for selected ophthalmic diagnostic tests and clinical characteristics of chinchilla eyes (Chinchilla lanigera). Vet. Ophthalmol. 13, 29-34.

Ofri, R., Horowitz, I.H., Raz, D., Shvartsman, E. and Kass, P.H. 2002. Intraocular pressure and tear production in five herbivorous wildlife species. Vet. Rec. 151(9), 265-268.

Prashar, A., Guggenheim, J.A., Erichsen, J.T., Hocking, P.M. and Morgan, J.E. 2007. Measurement of intraocular pressure (IOP) in chickens using a rebound tonometer: quantitative evaluation of variance due to position inaccuracies. Exp. Eye Res. 85(4), 563-571.

Rajaei, S.M., Ansari Mood, M., Khorram, H., Selk Ghaffari, M. and Williams, D.L. 2015. Measurement of Tear Production Using the Phenol Red Thread Test in the Common Mynah (Acridotheres tristis). J. Avian Med. Surg. 29(2), 146-148.

Reuter, A., Müller, K., Arndt, G. and Eule, J.C. 2010. Accuracy and reproducibility of the TonoVet rebound tonometer in birds of prey. Vet. Ophthalmol. 13(Suppl. 1), 80-85.

Reuter, A., Müller, K., Arndt, G. and Eule, J.C. 2011. Reference intervals for intraocular pressure measured by rebound tonometry in ten raptor species and factors affecting the intraocular pressure. J. Avian Med. Surg. 25(3), 165-172.

Stiles, J., Buyukmihci, N.C. and Farver, T.B. 1994. Tonometry of normal eyes of raptors. Am. J. Vet. Res. 55(4), 477-479.

Storey, E.S., Carboni, D.A., Kearney, M.T. and Tully, T.N. 2009. Use of phenol red thread tests to evaluate tear production in clinically normal Amazon parrots and comparison with Schirmer tear test findings. J. Am. Vet. Med. Assoc. 235(10), 1181-1187.

Van Dijk, A., Hustings, F., Boele, A., Koffijberg, K., Zoetebier, D. and Plate, C. 2010. Rare and colonial breeding birds in The Netherlands in 2006-2007. Limosa. 83, 1-20.

Willis, A.M. and Wilkie, D.A. 1999. Avian Ophthalmology. 1. Anatomy, Examination, and Diagnostic Techniques. J. Avian Med. Surg. 3, 160166. 